\title{
CУAYACHITPOSगЕVI SPRTMHAIICTRTh
}

УДК 343.98

В. Ю. Шепітько, завідувач кафедри криміналістики Національного юридичного університету імені Ярослава Мудрого, доктор юридичних наук, професор, академік НАПрН України

\section{ЦІЛЬОВЕ ПРИЗНАЧЕННЯ КРИМІНАЛІСТИЧНИХ ЗНАНЬ І ПРАГНЕННЯ ДО ЄВРОПЕЙСЬКИХ СТАНДАРТІВ У ПРОТИДІї ЗЛОЧИННОСТІ}

Розглянуто становлення й розвиток криміналістичних знань $і$ їх иільове спрямування. Визначено суб'єктів застосування криміналістичних знань у різних краӥнах світу та в різні історичні періоди. Простежено тендениії щзодо змінення суб 'єктів застосування криміналістичних знань у змагальному кримінальному процесі. Акцентовано увагу на формуванні «змагальної криміналістики», криміналістики для сторони обвинувачення та сторони професійного захисту, а також криміналістики для суду (судової криміналістики). Запровадження прогресивних європейських стандартів, розширення способів судового захисту особи в кримінальному провадженні та засобів доказування пов'язане із зміненням криміналістичного інструментарію, пропонуванням методів, прийомів і технологій, ще використовуються в протидії злочинності.

Ключові слова: криміналістика, криміналістичні знання, змагальний кримінальний прочес, європейські стандарти, протидія злочинності, слідчий, слідчий суддя, тенденції криміналістики.

Важливою тенденцією криміналістики на сучасному етапі ії розвитку $\epsilon$ інтеграція знань, їх об'єднання, спрямоване на оптимальне вирішення завдань протидії злочинності. У цьому сенсі Р. Юрка та Е. В. Курапка справедливо підкреслюють, що вибір інструментарію для боротьби зі злочинністю, користуючись лише національними правовими засобами, виявляється всетаки недостатнім. Щодня суспільство, яке стає все більш сучасним, визначає й розвиток так званої «злочинної індустрії», обумовлює також потребу в контролі над злочинністю за допомогою міжнародного елемента ${ }^{1}$. Для сучасного суспільства в СС характерним є розроблення спеціальних програм у межах бачення криміналістики та судової експертизи до 2020 р. (European Vision of Forensic Science area 2020) ${ }^{2}$.

${ }^{1}$ Юрка Р., Курапка Э. В. Криминалистика в международном сотрудничестве в уголовном процессе: в направлении взаимного признания. Криминалистика и судебная экспертиза: наука, обучение, практика. Vilnius, Charkovas, 2013. Ч. II. C. 74, 75.

2 Vision for Forensic Science 2020 and a New Ideas on its Future/E. V. Kurapka, H. Malevsky, S. Matuliene, E. Bileviciute. Criminalistics and forensic expertology: science, studies, practice. Vilnius, 2017. Ch. 1. P. 44, 45.

(C) Шепітько В. Ю., 2017 
Перші уявлення щодо криміналістики як науки свідчать про формування «наукової дисципліни», «спеціального вчення», «допоміжної науки» для судових слідчих і чинів жандармерії та поліції․․ У передмові до 3-го видання «Керівництва для судових слідчих» Г. Гросс зазначав, що кримінальне право не є наукою для себе, і найбільш цінні $з$ положень, що ним були встановлені (наприклад, про умисел, необережність, співучасть, замах, необхідну оборону, непереборну силу тощо), мають зрештою лише одну мету отримати практичне застосування. Але всі ці положення позбавлені будьякого значення, якщо суддя не зможе застосувати ці абстрактності до реальностей повсякденного життя; якщо він не розуміє або неправильно оцінює показання свідків, значення їх спостережень, якщо його вводять в оману прийоми зловмисників, якщо він не зможе використати сліди злочину, і якщо він взагалі не знайомий із численними положеннями, сукупність яких складає криміналістику ${ }^{2}$. Підкреслюючи роль криміналістики, Г. Гросс пише, що презентована як допоміжна наука для кримінального права, криміналістика, однак, залишає за собою право на самостійність: адже фактично вона існувала завжди й раніше. Той, хто оглядав сліди від людських ніг, хто зафіксував у пам'яті слово зі злодійського жаргону, хто накреслив план місця події, - кожний з них застосував ті або інші положення криміналістики ${ }^{3}$.

Становлення та розвиток криміналістики в різних країнах світу відбувається своєрідно, але й відбиває ії інтегративну функцію та цільове призначення. Процес розвитку криміналістики та інтеграція наукових знань простежуються вже в найменуваннях наукових дисциплін: «Forensic Sciences» (судові науки) у США, Великій Британії, Канаді, Австралії; «Kriminalistik» (криміналістика) у Німеччині, Австрії; «Police Scientifique» (наукова поліція) у Франції, Швейцарії. В англомовних країнах поряд з терміном «Forensic Sciences» використовують також й інші: «Criminalistics» (як частину судових наук), «Criminal Investigation» (кримінальне розслідування), «Criminology» (кримінологія) ${ }^{4}$. Різне тлумачення сутності криміналістичного знання $\epsilon$ наслідком невизначеності предмета науки, від чіткого розуміння якого завжди залежало постановлення головних завдань ії розвитку. Уявлення про предмет криміналістики, який сформувався в конкретний історичний період, визначав головні напрями наукових досліджень у цій галузі знання ${ }^{5}$.

У сучасному вигляді криміналістика являє собою цілісну систему наукового знання. І. Т. Кривошеїн підкреслює, що нині, коли в криміналістиці відбувається інтенсивне зростання знань, особливо актуальними стають

${ }^{1}$ Гросс Г. Руководство для судебных следователей как система криминалистики. Новое изд., перепеч. с изд. 1908 г. М.: ЛексЭст, 2002. 1088 с.

${ }^{2}$ Там само. C. VIII-IX.

3 Там само. C. IX.

${ }^{4}$ Шепитько В. Интегративная функция криминалистики и ее роль в реализации стратегических задач противодействия преступности в современных условиях. Криминалистика и судебная экспертология: наука, обучение, практика. Vilnius, 2017. Ч. I. C. $58-68$.

5 Эксархопуло А. А. Криминалистика: учебник. СПб., 2009. С. 12. 
інтеграційні процеси. Сьогодні як ніколи необхідне формування іншого погляду стосовно цілісності криміналістики, iї тлумачення не стільки в розумінні функціонування як деякої монолітної цілісності, скільки як трансдисциплінарної науки. Криміналістика повинна по-новому відкритися сучасному суспільству, світу науки, праву, кримінальному судочинству ${ }^{1}$.

Криміналістичні знання мають своє цільове призначення. Г. Кендзерска вказує, що розвиток криміналістики завжди повинен бути націлений на вирішення головного питання: хто залишив слід або хто вплинув на утворення слідів злочину? Ідентифікація слідоутворюючого об'єкта є пріоритетною метою кожної галузі криміналістики. Хоча розвиток криміналістики відбувається за непростим руслом та інколи складно зрозуміти ії течію, меандри в лабіринтах боротьби зі злочинністю, то зрештою усе, що з нею відбувається або що буде відбуватися в майбутньому, так чи інакше слугує розкриттю злочинів ${ }^{2}$.

Широко відоме «Керівництво» Г. Гросса було розраховане на відповідного суб'єкта - судового слідчого (особлива посадова особа судового відомства) ${ }^{3}$. Діяльність судового слідчого $є$ невід'ємною частиною здійснення правосуддя. Г. Гросс указує, що та держава, яка для боротьби зі злочином, що безперервно прогресує щодо витонченості прийомів і освітнього рівня своїх діячів, висуває суддів, які мають звичайну або видатну наукову юридичну освіту, але водночас не мають спеціальної, необхідної для С. С. (cyдового слідчого - курсив наш $B$. $U$.) підготовки, - неправильно розуміє свої завдання ${ }^{4}$.

У радянський період на теренах СРСР крен було зроблено в бік фігури слідчого, криміналістика розглядалася лише як наука для забезпечення слідчої діяльності, фактично знаходилася «на службі слідства». І. Т. Кривошеїн слушно зауважує, що в цей час переваги були віддані «процесу розслідування злочинів». Лише на перший погляд це зміщення науково-пізнавального акценту може здатися несуттєвим. У реальності це потягнуло за собою кінцеве витіснення з предметної галузі криміналістики такого феномену, як злочин зі всіма наслідками. Криміналістика зосередилася на пізнанні матеріальних слідів злочину, на збиранні, оцінюванні та використанні доказів, на пізнанні процесу доказування ${ }^{5}$. При цьому слідство як таке було реально «відірване» від судової діяльності, кримінальний процес був розшуковим (інквізиційним). У цей період єдиним споживачем і суб'єктом застосування криміналістичних знань був слідчий. Уся криміналістика була розрахована на роботу слідчого, розроблення для нього науково-технічних засобів, формування тактичних прийомів і рекомендацій виконання слідчої

\footnotetext{
${ }^{1}$ Кривошеин И. Т. Интегративная роль криминалистики в уголовном судопроизводстве. Вестник Том. гос. ун-та. Томск, 2010. № 336. С. 113.

${ }_{2}^{2}$ Кендзерска Г. Меандры криминалистики XXI века. Криминалистика и судебная экспертиза: наука, обучение, практика. Vilnius, Charcovas, 2013. Ч. II. С. 57.

3 В окремих випадках обов'язки судового слідчого покладалися на мирових суддів.

${ }^{4}$ Гросс Г. Зазнач. твір. С. 12, 13.

5 Кривошеин И. Т. Зазнач. твір. С. 112.
} 
діяльності. Головне завдання криміналістики того часу - оптимізація діяльності слідчого. В. М. Терехович підкреслює, що в кожній державі нормативно визначені суб'єкти розслідування злочинних діянь. Можлива різниця або схожість таких суб'єктів у різних державах є даністю, яка визначається особливістю історії та логіки соціального й політичного розвитку конкретної держави ${ }^{1}$.

Реформування кримінальної процесуальної діяльності в Україні, перехід на реальні рейки змагального процесу призводить до змінення суб' єктів, які використовують криміналістичні знання. Нині мова може йти про формування «змагальної криміналістики», криміналістики для сторони обвинувачення та сторони професійного захисту, а також криміналістики для суду (судової криміналістики) ${ }^{2}$.

У різних країнах світу виявляється певна тенденція, яка пов'язана із необхідністю забезпечення різних суб'єктів кримінальної процесуальної діяльності криміналістичними знаннями. Х. Колецкі зазначає, що криміналістика $€$ «науковою базою» одного з напрямів практичної діяльності правоохоронних органів і органів юстиції, інших органів правового захисту та експертів, у якому вони застосовують криміналістичні знання ${ }^{3}$. I. І. Когутич слушно зауважує, що одним із пріоритетних напрямів підвищення якості судового розгляду кримінальних справ слугує послідовне напрацювання й запровадження в практику положень судової тактики, судової методики розгляду різноманітних категорій кримінальних справ ${ }^{4}$. Ця тенденція знаходить своє підтвердження й у розробленні та пропонуванні відповідних наукових і навчальних матеріалів із «криміналістичної адвокатології» обвинувачів» ${ }^{6}$, судової криміналістики ${ }^{7}$ та ін.

Запровадження європейських стандартів і врахування європейської судової практики суттєво впливають на необхідність певної уніфікації процедур і засобів процесуальної діяльності. Прагнення до ефективного досягнення цілей кримінальної юстиції передбачає необхідність затвердження взаємного визнання процесу, безумовне визнання досліджень криміналістичних лабораторій і послуг, що вони надають, експертів, їх кваліфікації, компетенції тощо ${ }^{8}$.

${ }^{1}$ Терехович В. Н. Теория криминалистики. Общая часть: монография. Рига, 2015. C. 103.

${ }^{2}$ Шепитько В. Зазнач. твір. С. 58-68.

3 Колецки $X$. Современное состояние криминалистики как университетской дисциплины в Польше. Криміналіст периодрукований. 2012. № 5. С. 29.

${ }^{4}$ Когутич I. I. Використання знань та засобів криміналістичної тактики і методики під час розгляду кримінальних справ у суді: монографія. Львів: Тріада плюс, 2009. C. $3,4$.

${ }^{5}$ Баев М. О. Тактические основы деятельности адвоката-защитника в уголовном судопроизводстве. Воронеж: Воронеж. гос. ун-т, 2004. 220 с.

${ }_{6}^{6}$ Криминалистика для государственных обвинителей: учебник/под ред. А. Ф. Козусева, В. Н. Исаенко, А. М. Кустова. М.: Норма: ИНФРА-М, 2012. 480 с.

7 Когутич I. I. Криміналістичні знання, їх сутність і потреба розширення меж використання: монографія. Львів: Тріада плюс, 2008. 420 с.

${ }^{8}$ Юрка Р., Курапка Э. В. Зазнач. твір. С. 75. 
В Україні відбулися суттєві зміни в процесуальній діяльності з прийняттям КПК 2012 р. В. Д. Бринцев підкреслює, що «прийняття нового КПК України є лише певним етапом у розбудові системи захисту прав і інтересів особистості, слід оперативно аналізувати правозастосовну практику, виявляти суттєві прогалини і формувати пропозиції щодо удосконалення кримінального провадження за стандартами правової держави» ${ }^{1}$ В. Т. Маляренко вказує, що «однією з перепон, що заважають Україні приєднатися до європейської спільноти, набути статусу рівноправного члена європейських міжнародних структур, є проблема із забезпеченням справедливого розгляду кожної справи у суді, адже справедливий розгляд кримінальних справ, крім інших умов, можливий лише за наявності такої процедури, яка забезпечує кожній людині захист ії прав і законних інтересів»².

У нормах КПК України регламентуються положення, які грунтуються на сучасних досягненнях криміналістики (криміналістичної техніки): пред'явлення особи для впізнання поза ï візуальним та аудіоспостереженням (ч. 4 ст. 228 КПК); під час допиту може застосовуватися фотозйомка, аудіо- та/або відеозапис (ч. 5 ст. 224 КПК); проведення допиту, упізнання в режимі відеоконференції під час досудового розслідування (ст. 232 КПК); допит малолітнього або неповнолітнього свідка чи потерпілого поза залом судового засідання в іншому приміщенні з використанням відеоконференції (дистанційне судове провадження) (ч. 4 ст. 354 КПК) та ін. Або передбачаються в нормах КПК України певні «тактичні поради»: оголошення показань при допиті під час судового розгляду (ч. 5 ст. 225 КПК); оголошення показань, наданих учасниками допиту на попередніх допитах (ч. 9 ст. 224 КПК); постановка додаткових запитань (ч. 7 ст. 224 КПК); заборона ставити навідні запитання під час прямого допиту (ч. 6 ст. 352 КПК) тощо.

У кримінальному процесуальному законодавстві суттєво змінюється функціональне призначення слідчого, обмеження його лише «обвинувальною функцією». За КПК України слідчий є стороною обвинувачення (§ 2 гл. 3 КПК).

У п. 17 ч. 1 ст. 3 КПК України передбачено, що слідчий - службова особа органу внутрішніх справ, органу безпеки, органу, що здійснює контроль за додержанням податкового законодавства, органу державного бюро розслідувань, уповноважена в межах компетенції здійснювати досудове розслідування кримінальних правопорушень. У ст. 40 КПК України визначено повноваження слідчого органу досудового розслідування. На сьогодні роль слідчого суттєво обмежена процесуальними механізмами (судовим контролем, процесуальним керівництвом з боку прокурора та ін.). Слідчий фактично перетворюється на «додаткову» процесуальну фігуру.

У зв'язку із реформуванням судової системи та органів правопорядку з'являються також і нові суб'єкти, які використовують криміналістичні знан-

${ }^{1}$ Бринцев В. Д. Права людини і законодавство України. Юрид. часопис Нац. акад. внутр. справ. 2013. № 1. С. 120.

${ }_{2}^{2}$ Маляренко В. T. Перебудова кримінального процесу України в контексті європейських стандартів: монографія. Київ: Юрінком Інтер, 2005. С. 30, 31. 
ня: сторони кримінального провадження, процесуальний керівник, керівник органу досудового розслідування, слідчий суддя та ін. Крім того, реформування всієї правоохоронної системи, створення нових інституцій (зокрема, у сфері протидії корупції), пов'язане з появою специфічних службових осіб - детективів (особи, які поєднують слідчу та оперативну діяльність). Розроблюються також правові підстави для створення розшукових служб приватних детективних агенцій (приватних детективів).

Виникає запитання - кому повинна служити криміналістика? Використання криміналістичних знань передбачає здійснення пізнавальної діяльності у сфері правосуддя. Цільова спрямованість різних суб’єктів цієї діяльності має бути пов'язана із відновленням справедливості, досягненням істини. Тому в змагальному кримінальному процесі суб'єктом використання криміналістичних знань може бути не лише слідчий, а й сторони кримінального провадження, інші суб'єкти, що наділені відповідними повноваженнями (наприклад, процесуальний керівник, детектив, слідчий суддя та ін.), а також суд ${ }^{1}$.

Використання криміналістичних знань у змагальному кримінальному процесі має забезпечувати сторони кримінального провадження належним інструментарієм, науковим апаратом, техніко-криміналістичними засобами та інформаційними технологіями, передбачає недопущення або усунення судових та інших помилок, досягнення справедливості й вирішення соціального конфлікту. Сучасний судовий процес повинен відбуватися на наукових засадах із використанням новітніх криміналістичних методів, прийомів і технологій (інформаційних, інтерактивних, комунікативних та ін.).

В Україні з 2017 р. розпочався процес імплементації конституційних змін щодо правосуддя. 3 жовтня 2017 р. Верховна Рада України ухвалила закон про судову реформу (законопроект № 6232), який передбачає внесення змін до процесуальних кодексів та інших законодавчих актів. На сьогодні Президент П. Порошенко підписав Закон «Про внесення змін до Господарського процесуального кодексу України, Цивільного процесуального кодексу України, Кодексу адміністративного судочинства України та інших законодавчих актів». Уносяться відповідні зміни й щодо правил кримінального процесу. Головна мета змінення законодавства - привести правила судового процесу у відповідність до кращої європейської та міжнародної практики.

Запровадження прогресивних європейських стандартів ${ }^{2}$, системи «електронного суду», розширення способів судового захисту особи в кримінальному провадженні та засобів доказування - безперечно пов'язане із застосуванням сучасних методів і технологій криміналістики, використанням можливостей наукового забезпечення судового процесу, залученням широкого арсеналу спеціальних знань і судових експертиз. Додержання прав людини стає критерієм цивілізованості країн сучасного світу.

${ }^{1}$ Шепитько В. Зазнач. твір. С. 58-68.

2 Європейські та міжнародні стандарти у сфері судочинства. Київ, 2015. 708 с. 


\section{ЦЕЛЕВОЕ ПРЕДНАЗНАЧЕНИЕ КРИМИНАЛИСТИЧЕСКИХ ЗНАНИЙ И СТРЕМЛЕНИЕ К ЕВРОПЕЙСКИМ СТАНДАРТАМ В ПРОТИВОДЕЙСТВИИ ПРЕСТУПНОСТИ}

\section{Шепитько В. Ю.}

Рассмотрено становление и развитие криминалистических знаний и их целевая направленность. Определены субъекты применения криминалистических знаний в различных странах мира и в разные исторические периоды. Прослежены тенденции относительно изменения субъектов применения криминалистических знаний в состязательном уголовном процессе. Акцентировано внимание на формировании «состязательной криминалистики», криминалистики для сторонь обвинения и стороны профессиональной защчтыь, а также криминалистики для суда (судебной криминалистики). Внедрение прогрессивных европейских стандартов, расширение способов судебной защиты личности в уголовном производстве и средств доказывания связаны с изменениями криминалистического инструментария, предложением методов, приемов и технологий, используемых в противодействии преступности.

Ключевые слова: криминалистика, криминалистические знания, состязательный уголовный процесс, европейские стандарты, противодействие преступности, следователь, следственный судья, тендениии криминалистики.

\section{DESIGNATED PURPOSE OF CRIMINALISTIC KNOWLEDGE AND AMBITION TO THE EUROPEAN STANDARDS IN COUNTERACTING CRIMINALITY}

\section{Shepitko $V$. Yu.}

The formation and development of criminalistic knowledge and their targeted purpose are considered. Subjects of applying criminalistic knowledge in different countries of the world and in different historical periods are defined. The tendencies concerning changes in the subjects of applying criminalistic knowledge in the adversarial criminal process are retraced. One of the tendencies of the past was the shift of the scientific-cognitive emphasis in favor of the investigating crimes process, which entailed the final displacement from the subject domain of Criminalistics of such phenomenon as the crime with all the consequences. Criminalistics focused on the cognition of the material traces of crime, on the collection, evaluation and use of evidence, cognition of proof process. During this period, the only consumer and subject of the use of criminalistic knowledge was the investigator. In connection with the reform of the judiciary and law enforcement bodies, there appear new subjects, using criminalistic knowledge: the parties of the criminal proceedings, the procedural head, the head of the pre-trial investigation body, the investigating magistrate, etc. In addition, reforming of the entire law enforcement system, the creation of new institutions (in particular, in the area of corruption counteraction), is associated with the emergence of specific officials - detectives (persons who combine investigative and operative activities). Legislative bases for creation of search services - private detective agencies (private detectives) are also being developed. Thus, the adversarial process leads to the change of the subjects using criminalistic knowledge. Now we can speak about the formation of "competitive criminalistics", criminalistics for the prosecution party and the professional protection party, as well as criminalistics for the court (forensic criminalistics). 
The introduction of progressive European standards, the expansion of the methods of judicial protection of an individual in the criminal proceedings and the means of proof is associated with the changes in criminalistic tools, with offering of methods, techniques and technologies used in countering criminality.

Keywords: criminalistics, criminalistic knowledge, adversarial criminal process, European standards, criminality counteraction, investigator, investigating magistrate, criminalistics tendencies.

УДК 343.98

B. A. Журавель, головний учений секретар Національної академії правових наук України, доктор юридичних наук, професор, академік НАПрН України

\section{ТАКТИЧНІ ЗАВДАННЯ ТА МЕХАНІЗМ ЇХ ВИРІШЕННЯ}

Розглянуто позииії та підходи науковиів щзодо визначення поняття «тактичне завдання». Звернуто увагу на те, що вирімувані завдання досудового розслідування доиільно за обсягом поділяти на основні (загальні, стрижневі) й локальні (проміжні), а за сферою реалізації-на стратегічні й тактичні. При иььому основні (загальні, стрижневі) завдання за своєю сутністю можна вважати стратегічними, оскільки вони зумовлені обставинами, котрі підлягають з 'ясуванню в иілому в ході розслідування конкретної категорії злочинів. Вони спрямовані на досягнення правової мети, за своєю природою є більш усталеними та меншою мірою піддаються впливу ситуаційних чинників. Локальні (проміжні) завдання слід розглядати як тактичні, оскільки вони зумовлені ситуаціями, щео виникають на певному етапі розслідування.

Ключові слова: тактичне завдання; ознаки тактичного завдання; види тактичних завдань; механізм вирімення тактичних завдань; прогнозування в механізмі вирішення тактичних завдань.

Досудове розслідування за своєю сутністю $є$ безперервним процесом прийняття уповноваженими суб'єктами відповідних рішень, спрямованих на розв'язання різноманітних завдань пізнавального, евристичного, процесуально-правового, тактико-психологічного, організаційного, матеріально-технічного характеру. У криміналістичній доктрині поняття «завдання» найчастіше застосовується в словосполученні «слідче завдання» або «криміналістичне завдання». У більшості випадків воно трактується як питання, що виникло в процесі розслідування, яке потребує свого вирішення або слідчим особисто, або за допомогою інших учасників кримінального провадження, окремих служб чи осіб. Категорія «завдання» використовується в криміналістиці як складовий елемент планування розслідування поряд 3 аналізом вихідної інформації, висуненням версій та ін. ${ }^{1}$

${ }^{1}$ Белкин Р. С. Курс криминалистики: в 3 т. Т. 2: Частные криминалистические теории. М.: Юристъ, 1997. С. 383.

(C) Журавель В. А., 2017 